University of Nebraska - Lincoln

DigitalCommons@University of Nebraska - Lincoln

Textile Society of America Symposium

Proceedings

Textile Society of America

2020

The Hidden Story of the Quilted Cover in the Benaki Museum

Collection

Sumiyo Okumura

Follow this and additional works at: https://digitalcommons.unl.edu/tsaconf

Digitalrt of the Art and Materials Conservation Commons, Art Practice Commons, Fashion Design

Commens, Fiber, Textile, and Weaving Arts Commons, Fine Arts Commons, and the Museum Studies

detwerkns

Logo

This Article is brought to you for free and open access by the Textile Society of America at

DigitalCommons@University of Nebraska - Lincoln. It has been accepted for inclusion in Textile Society of America

Symposium Proceedings by an authorized administrator of DigitalCommons@University of Nebraska - Lincoln. 
Published in Hidden Stories/Human Lives: Proceedings of the Textile Society of America 17th Biennial Symposium, October 15-17, 2020. https://digitalcommons.unl.edu/tsaconf/ Copyright $\odot 2020$ Dr. Sumiyo Okumura doi: $10.32873 /$ unl.dc.tsasp. 0121

\title{
The Hidden Story of the Quilted Cover in the Benaki Museum Collection
}

\author{
Dr. Sumiyo Okumura
}

I first saw the double faced quilted cover in the Benaki Museum collection in 2016 during a symposium at the museum.(Fig. 1 and 2) It piqued my interest because it looks like Mamluk textile, and I began researching it. Then, in 2018, Anna Ballian published a paper in which she proposed that the origin of this cover was the Island of Chios. ${ }^{1}$ I found this conclusion intriguing, for in my nine years working with Professor Dr. Hülya Tezcan at the Textile Department of Topkap1 Palace Museum, I had seen many Chios textiles, but never one like the Benaki cover. I decided to deepen my research on the origins of the quilted cover in the collection of the Benaki Museum to shed light on the hidden story.

\section{The double-faced quilted cover in the Benaki collection}

COVID-19 conditions forced me to carry out my research via Zoom with support from Mina Moraitou, curator of the Benaki Museum. The front quilted cover, which measures $209 \times 153 \mathrm{~cm}$, is made of thickened weft faced 4-shafts twill silk weave. The warps are not linen but most probably thick unrefined yellow-green silk and the wefts are degummed soft bright yellow silk. (Fig. 3) On the front side, three loom-width panels (approx. width $53 \mathrm{~cm}, 53 \mathrm{~cm}$, and $49 \mathrm{~cm}$ ) are sewn together. (Fig. 4) On both ends, the front cloth is folded back and sewn on the back cloth. The fabric on the back side is woven in plain with linen and then dyed with indigo (See Fig. 2), and three loom-width panels and one short border on the left are sewn together (approx. width 20 $\mathrm{cm}, 45 \mathrm{~cm}, 46 \mathrm{~cm}, 43 \mathrm{~cm}$ ). (Fig. 5) On the left short border, about $89 \mathrm{~cm}$ from the top, two fabrics are spliced together. We noticed that the outer border on the left side was missing. The left end of the cover may have been cut later, probably to adjust it to the size of a wall or a bed. We carefully looked for a stamp, but this cover does not bear one. A cover made on the Chios Islands in the Ottoman-era ordinarily would carry a custom stamp that reads Damga-i Sakız. ${ }^{2}$

\footnotetext{
${ }^{1}$ See: Anna Ballian, "From Genoa to Constantinople: The Silk Industry of Chios," in The Mercantile Effect, Art and Exchange in the Islamicate World during the 17th and 18t centuries, ed. Sussan Babaie and Melanie Gibson (London: Gingko, 2018), 87-101.

${ }^{2}$ Sakiz is the Turkish name for the Chios Island.
} 


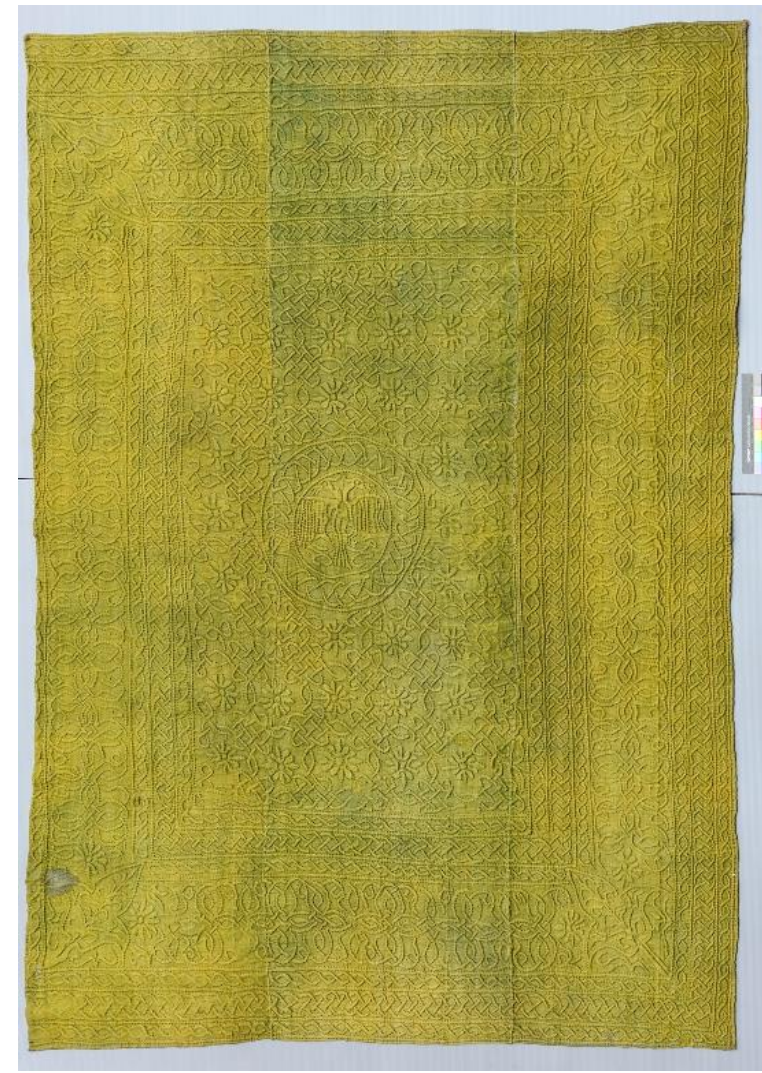

Fig. 1, Double faced quilted cover (front), $15^{\text {th }}$ century $209 \times 153 \mathrm{~cm}$, Athens, Benaki Museum, 63

(C) Benaki Museum-L. Kourgiantakis

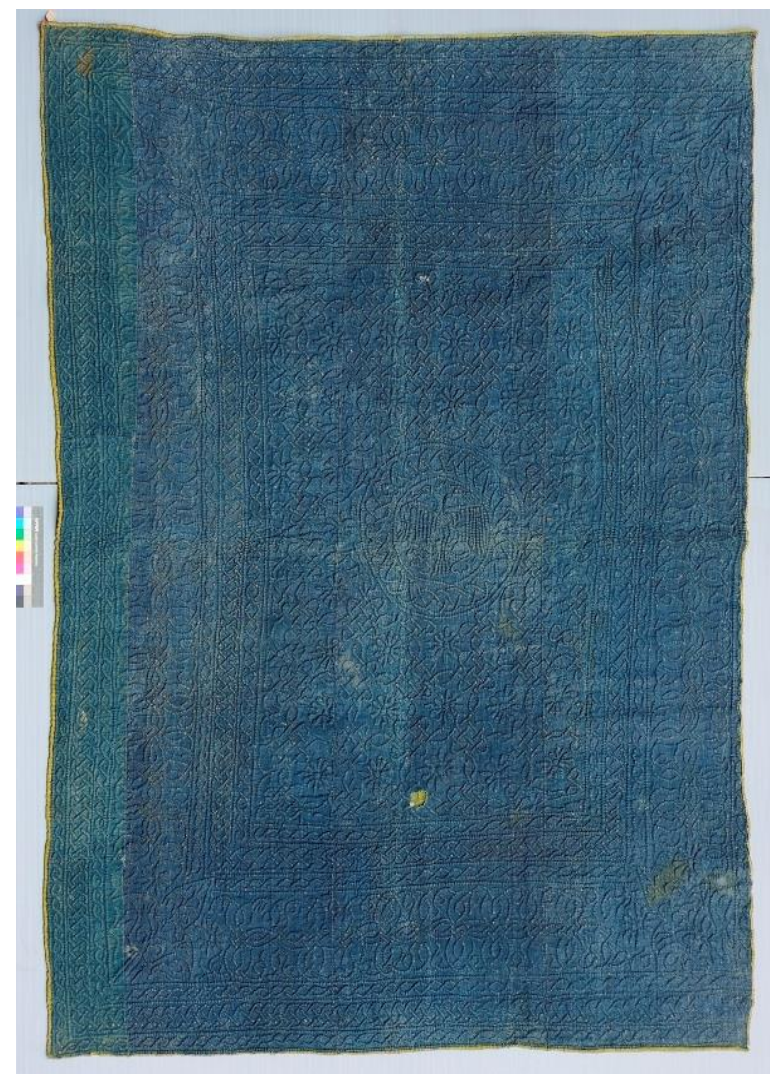

Fig. 2, Double-faced quilted cover (back) (C) Benaki Museum-L. Kourgiantakis
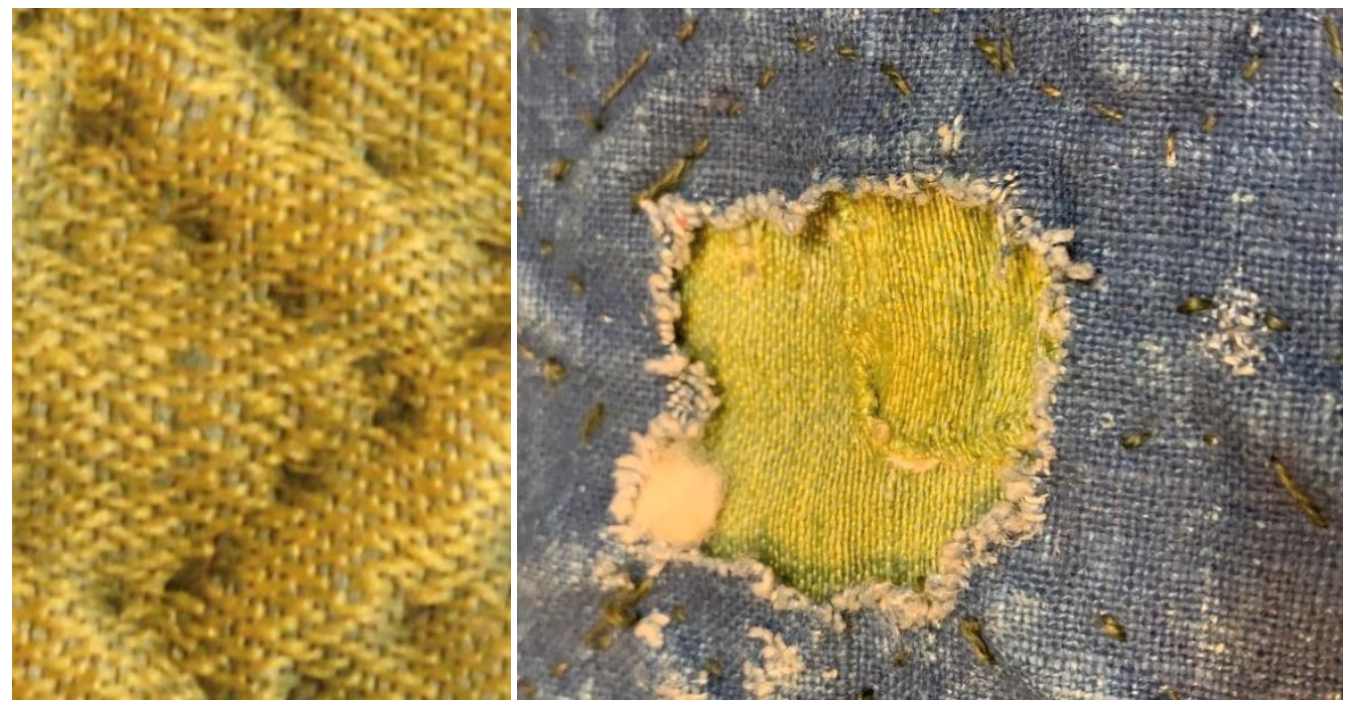

Fig. 3, Detail from the front and back side of the quilted cover 


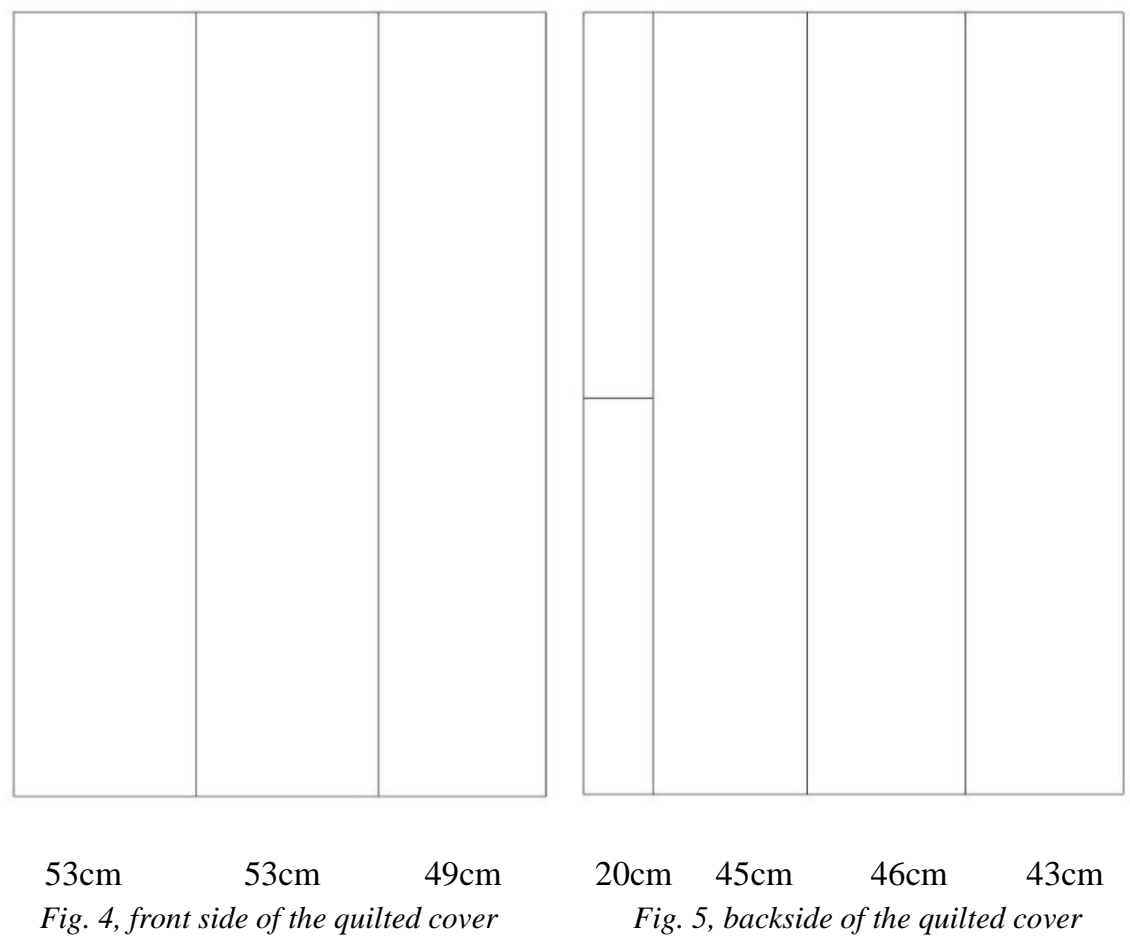

There is no interlining between the fabrics other than the raised-work with cordons. The designs are stitched with the running stitch technique using s-twisted threads of dark green or brown cordons, and are filled with cotton. (Fig. 6) This technique is called trapunto, which means "to embroider" in Italian and "to prick with a needle" in Latin. Trapunto is a quilting technique that is applied by inserting extra cotton wadding or cloth to the design to create a three-dimensional effect on the surface. According to Susanna Conti and Maria Stragapede, this technique was applied to textiles to provide additional cushioning and protection to the user, and to create plant figures and ornaments in decorative objects. ${ }^{3}$

On the surface, there are three borders and a main ground in the center; these are decorated with small 12 petaled flowers and geometric patterns, such as endless knots, created by lines using the trapunto technique. What is most interesting is the emblem of a double-headed eagle in the center of the cover. (Fig. 7) According to Ballian, this cover came from the Aegean island of Skyros and was purchased by the Benaki Museum from a descendant of the Faltaits family. ${ }^{4}$ Similar types of quilted covers are preserved in other museums, such as the Isabella Stewart

\footnotetext{
${ }^{3}$ Susanna Conti and Maria Stragapede, "Studio teorico-pratico della tecnica esecutiva" in La "coperta" Guicciardini Il restauro delle imprese di Tristano (Firenze, 2010), 67-80: 70.

${ }^{4}$ According to Ballian, another piece was owned by the Faltaits family on the island and currently kept in the local family museum, the Faltaits Historical and Folklore Museum in Skyros. See: Ballian, "From Genoa to Constantinople," 89.
} 


\section{Gardner Museum in Boston, ${ }^{5}$ Museo e Galleria Mozzi Bardini in Florence; ${ }^{6}$ and in a private collection in Florence.}

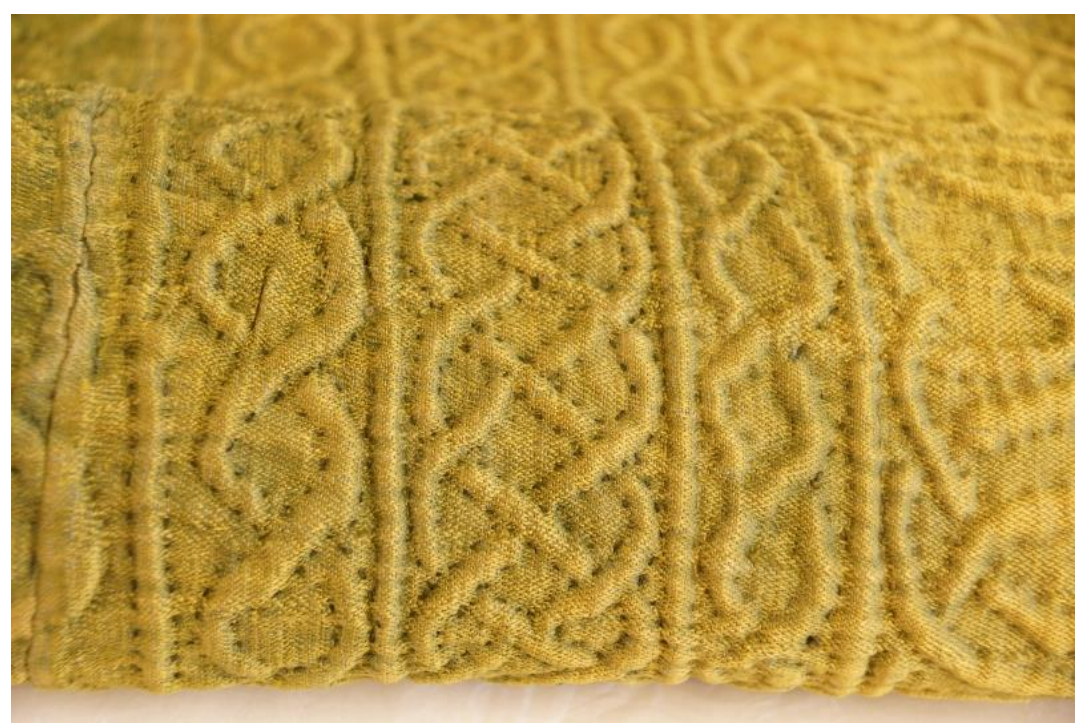

Fig. 6, detail from the quilted cover, Photo: Sumiyo Okumura

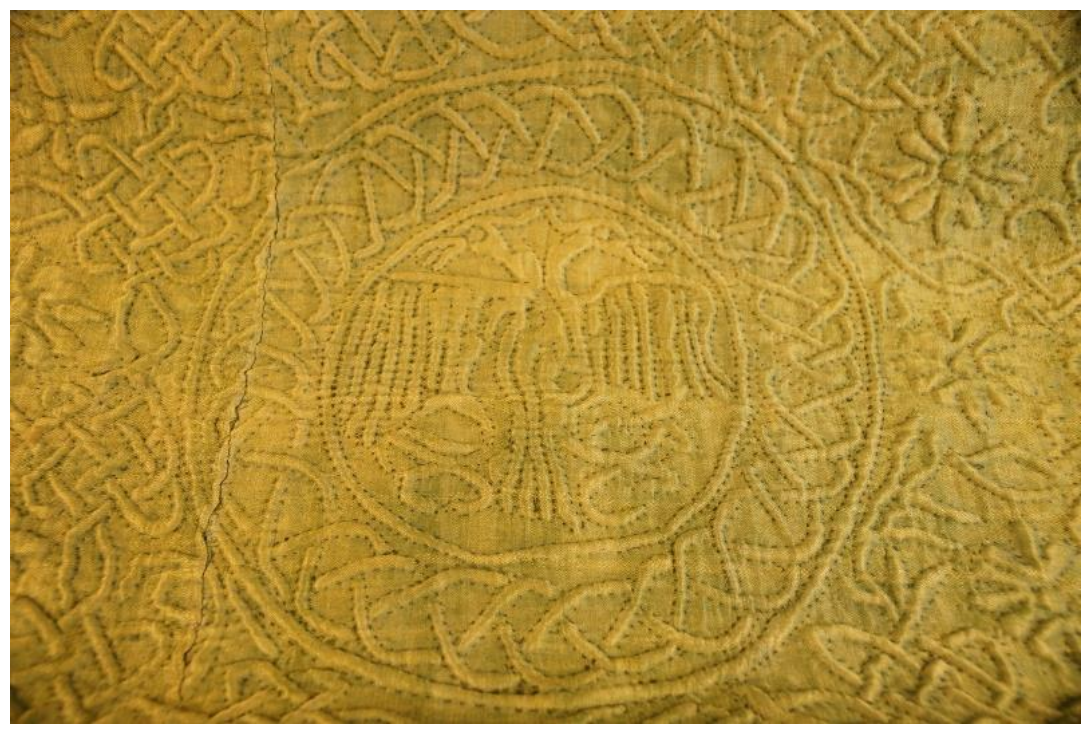

Fig. 7, the emblem of the double-headed eagle, Photo: Sumiyo Okumura

\footnotetext{
${ }^{5}$ inv.no.T17hig120. This quilted cover is made of silk with trapunto technique and the size is $248.9 \times 205.7 \mathrm{~cm}$. Some studies place this cover's origins in Southern Italy, 1450-1600. This quilted cover was purchased from Emilio Costantini in Florence in 1897. Like the Benaki piece, this cover is reversible: the front is made of yellowish green silk and the reverse is pale crimson silk. Cotton-filled cordons form geometric patterns, but the ground bears neither the emblem of double-headed eagle, nor the endless knot motifs. See: Adolph S. Cavallo, Textiles: Isabella Stewart Gardner Museum (Boston, 1986), 142, no. 89; Isabella Gardner Museum website:

https://www.gardnermuseum.org/experience/collection/13714

${ }^{6}$ This trapunto cover was recently discovered by Dr. Alberto Boralevi and Dr. Mario Mozzo at the Museo e Galleria Mozzi Bardini in Florence. I plan to do further research on this object.
} 


\section{Fragment in a private collection in Florence}

A similar type of double-faced silk fragment, a so-called trapunto fiorentino, can be seen in a private collection in Florence. (Fig. 8) The condition of the fragment is quite worn, and it has been restored with transparent silk gauze called velo di Lione (Lyon's veil) or crepeline. The size of the fragment is $54 \times 31 \mathrm{~cm}$; the front side is made of yellowish green silk, while dark red silk was used on the back side. (Fig. 9) Like the Benaki piece, cotton-filled cordons form geometrical motifs such as endless knots and small flowers. As the silk on the surface faded out, these images reveal how cordons were placed between textiles. The sewing thread is ivory / yellow s-twisted silk. (Fig. 10) This fragment was likely made in the 15th century, judged by the thin silk materials and the style of the design and patterns.

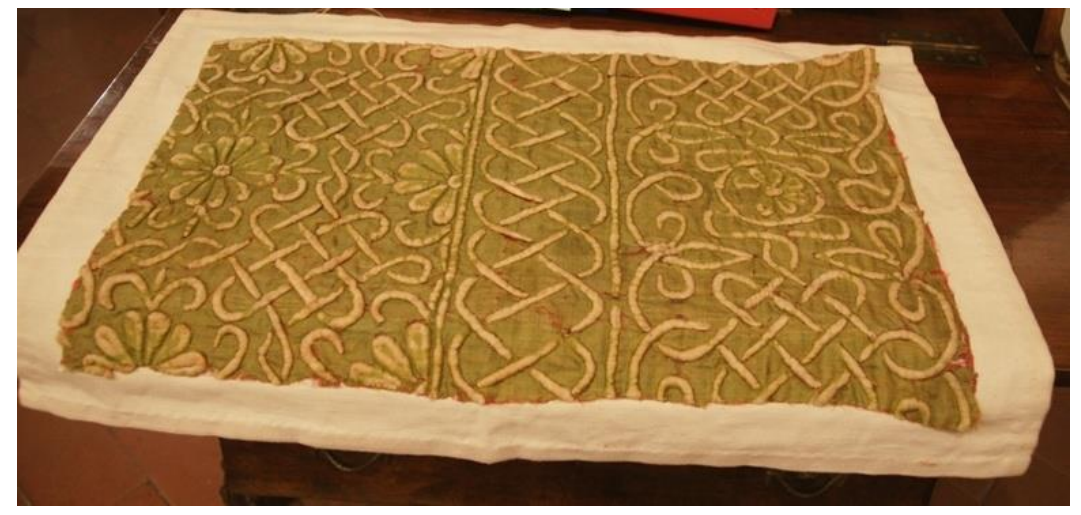

Fig. 8, Fragment of the double-faced trapunto fiorentino

Silk, cotton, $54 \times 31 \mathrm{~cm}$, 15th century, private collection, Italy. Photo: Sumiyo Okumura

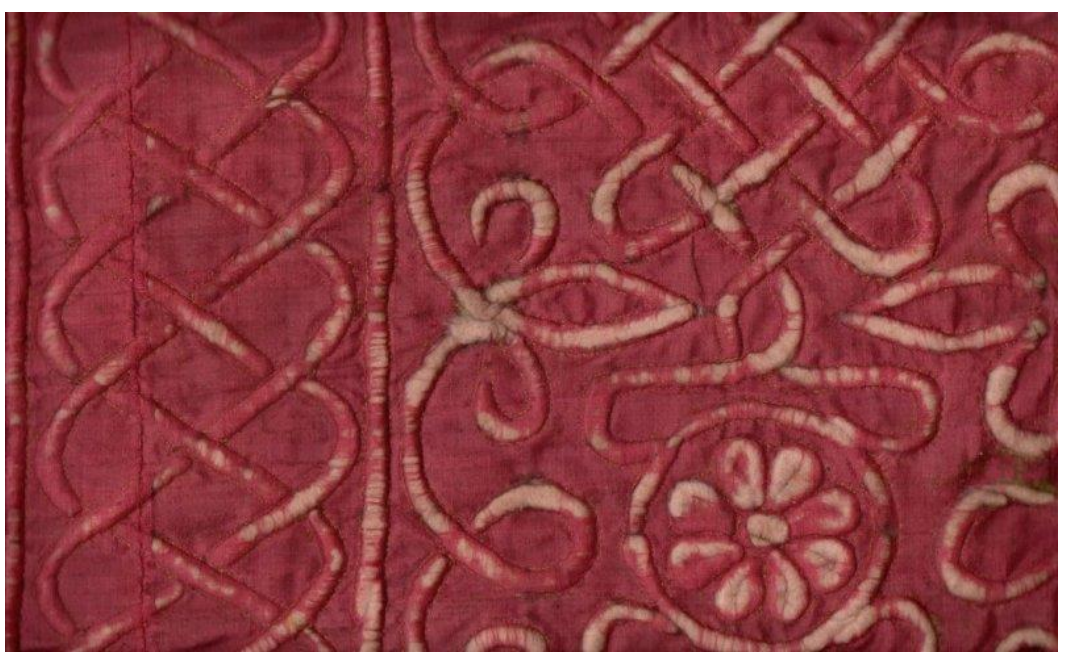

Fig. 9, Detail from the backside of the fragment. Photo: Sumiyo Okumura 


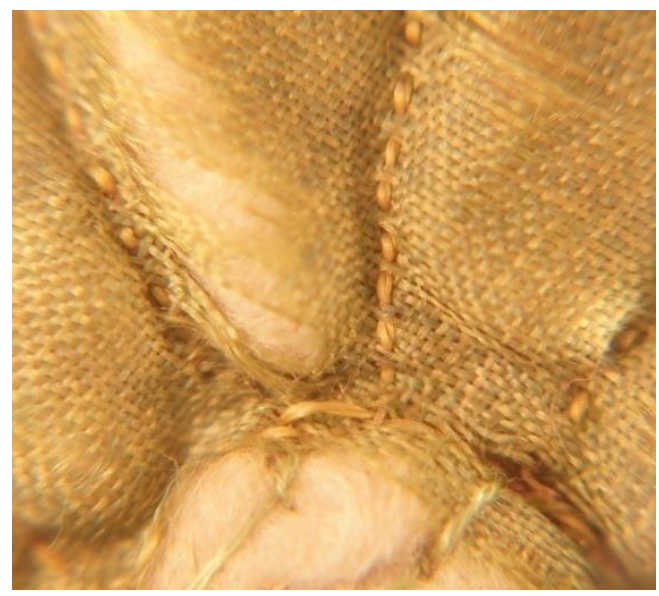

Fig. 10, Detail from the front side of the fragment. Photo: Sumiyo Okumura

\section{Historical background of the quilted cover}

A comparative analysis of these textiles raises the question of where and when this type of quilted cover was made. My initial assumption was that it was made in Egypt due to the similarity with colors and geometric designs that we see in Mamluk textiles. We find quilting techniques applied on several caps made in the Buyid or Seljuk period, as well as the Mamluk period. ${ }^{7}$ Endless knots and flowers with six or eight petals were common designs in Mamluk textiles.

The double or single-headed eagle is a symbol of power associated with the concept of empire. It originated in Mesopotamian art and continued to exist in the Sassanid and Byzantine periods. We also find it frequently in Islamic art, especially in the Seljuk Empire and Rum Seljuk sultanate. This culture spread to North Africa, Spain and Sicily and although it originated in the East, it was well entrenched in the West by the modern period. ${ }^{8}$ The emblem of eagle was also used by the Ayyubids and Mamluks. The wall of the Citadel in Cairo bears an emblem of an eagle, carved in stone, attributed to Salah al-Din. Famous Ottoman traveler Evliya Çelebi mentions that it originally featured a double-headed eagle. ${ }^{9}$ Amir Toquztimur, the saqi and majordomo of Sultan Nasir al-Din Muhammad and a governor of Damascus, used his master Sultan Nasir al-

\footnotetext{
${ }^{7}$ Quilted cap with star patterned silk Iran or Iraq, Buyid or Seljuk period, 11th century, Cleveland Museum of Art collection, John L. Severance Fund, 1950.525 and quilted cap with striped and inscribed silk, attributed to Sultan Qala'un. Egypt, 14th century, Cleveland Museum of Art collection, John L. Severance Fund, 1950.510.

${ }^{8}$ See: Pascal Androudis, "Double-headed Eagles on Early (11th-12th C.) Medieval Textiles Aspects of Their Iconography and Symbolism," in Niš i Vizantija: cetrnaesti medunarodni naucni skup, Niš, 3.-5. Jun 2015: zbornik radova XIV: Dani Sv. cara Konstantina i carice Jelene (Niš and Byzantium: Fourteenth International Symposium, Niš, 3-5 June 2015: the collection of scientific works XIV: The Days of St. Emperor Constantine and Helena), ed. Rakocija, Miša B. (Nis, 2016), 315-342.

${ }^{9}$ Doris Behrens-Abouseif, Islamic Architecture in Cairo: An Introduction (Leiden; New York: E.J. Brill, 1989), 80: Prof. Abouseif says that the emblem of eagle had been located elsewhere, for its present location is atop of a wall, that was rebuilt several times.; Nasser O Rabbat, The Citadel of Cairo (Supreme Council of Antiquities, 2009), 9.
} 
Din Muhammad's heraldic blazon, single or double-headed eagle, on several objects. ${ }^{10}$ A flask made in Syria bears a similar composite blazon with a single-headed eagle and flowers. ${ }^{11}$ These resemble the designs on the Benaki quilted cover, though the flask features a single-headed rather than double-headed eagle.

Researching examples of similar fabrics in Arabic archives is difficult, as the sources in those archives rarely use the terms "quilted" or "quilted cover." It seems that there was no designated Arabic word for quilts or quilted. The Arabic terms milhaf ملحف and milhafa ملحفة (pl. malähif

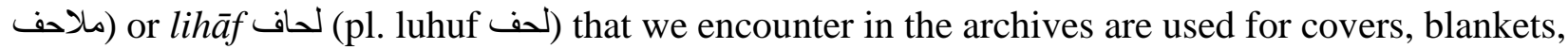
bed-sheets, wraps and quilts. ${ }^{12}$ According to the Lane's Arabic-English Lexicon, the public referred to lined or stuffed (quilted) covers as milhafa. ${ }^{13}$ Non-lined or single-stuffed wraps, milhafa, were sometimes used as night covers, ${ }^{14}$ likely similar to the Turkish quilted blanket, yorgan. Even if the material used was a quilted textile, the object may have been named differently based on its usage. For example, a geography book titled Hudud al-'Alam written in 982 C.E. tells us that quilted garments (kazagand) and cotton stuffs (karbas) were produced in Kath of Khoresm. ${ }^{15}$ Poet, author and nobleman Usama ibn Munqidh (1095-1188) also refers in his Kitab al-I'tibar, to a nice Gaza saddle, with a quilted center (munabbat). ${ }^{16}$

In a Makkari's catalog of textiles, gifted to al-Nasir in 939, that was copied from the list written by Ibn Khaldun and Ibn al-Faradi, we encounter the term milhaf. The item is described as 48 "Bagdad" milhaf covers with six Iraq tents (suradik) for the adornment of horses, of silk and gold. ${ }^{17}$ There is another mention of "one hundred Zahri coverlets (milhafa) for al-Nasir's bed." 18 Serjeant notes that this type of items can be found elsewhere.

Although there are no surviving examples, milhafa, translated as a quilted mantle, is mentioned in a Genizah manuscript, a marriage agreement concluded between Ben Yiju and Sitt al-Dar in 1156. ${ }^{19}$ We understand from this description that milhafa was used in Cairo in the 12th century. In another document, a letter from a Jewish trader, the word malahif refers to a cloak. What

\footnotetext{
${ }^{10}$ Esin At1l, Renaissance of Islam Art of the Mamluks (Washington D.C., 1981), 92-93.

11 At1l, Renaissance of Islam Art of the Mamluks, 190.

12 J.G. Hava, s.j., Arabic-English Dictionary for the use of students (Beirut: Catholic Press, 1915), 680; J.G. Hava s.j, Al-Faraid Arabic-English Dictionary (Beirut: Catholic Press, 1964), 680; Hans Wehr, A Dictionary of Modern Written Arabic, ed. J. Milton Cowan, Third Printing (Wiesbaden: Otto Harrassowitz, 1980), 860; R. P. A. Dozy, Dictionnaire détaillé des noms des vêtements (Amsterdam 1845) 401-402; R. B. Serjeant, Islamic Textiles, Material for a History up to the Mongol Conquest (Lebanon: Beirut, 1972), 162, 204, 42: note 17, 253; Book of Gifts and Rarities (Kitab al-Hadaya wa al-Tuhaf), trans. Ghada al-Hijiawi al-Qaddumi (The President and Fellows of Harvard College, 1996), 429.

${ }^{13}$ Edward William Lane, An Arabic-English Lexicon, Book I, Part 8, ed. Stanley Lane-Poole (London: Williams and Norgate, 1885), 3008; also see: http://lexicon.quranic-research.net/pdf/Page_3008.pdf.

${ }^{14}$ Lane 1885, 3008; Book of Gifts and Rarities, 429.

${ }^{15}$ Serjeant, Islamic Textiles, 105.

${ }^{16}$ Serjeant, Islamic Textiles, 162.

${ }^{17}$ Serjeant, Islamic Textiles, 28, 168.

${ }^{18}$ Serjeant, Islamic Textiles, 168.

${ }^{19}$ Genizah document, St. Petersburg Yvr-Arab. I. 1700, folio fol.28, fol. 6, T-S AS 153.320, page: 1r. See: https://fjms.genizah.org/
} 
makes this source noteworthy is that the author identified the origins of these textiles were as western, brought from the West, from Sicily or Majorca. ${ }^{20}$ From the 11th century onward, Sicily became an international trade center, ${ }^{21}$ and fabrics made in Sicily, Lucca, Florence, Genoa and Venice, were brought to the Levant together with other goods. This trade was conducted by Egyptian and Maghrebi Jewish merchants, as well as Genoese and Venetians merchants in the eastern Mediterranean. Quilted covers or cloaks were among merchandise brought from Sicily or Majorca to Egypt during the 12th century.

\section{Yorgan}

One of the oldest examples of quilted cover was discovered in Niya region in northwest China and dated to a period from the second century B.C.E. to the early fifth century C.E. ${ }^{22}$ This unlined quilted cover, made of two complete bolts of Jin silk, was used to wrap the body of a king, buried in a royal tomb of the Jinjue Kingdom, which ruled under the Han Dynasty.

Quilted covers were also used by the Turkic people of West Asia. During the Uyghur period in Central Asia, a quilted cover called yogurkan is mentioned in the archives. ${ }^{23}$ The word yorgen or yorgan comes from the word "yör": to cover, wrap, and cover up. In Kâşgarlı Mahmûd's 11th century Divanü Lugâti't Türk, the word yogurqan is used for quilts. ${ }^{24}$ Quilts are scribed as yorgan in the Ibn Mühennâ Lugât, dated to the 13th or 14th century, and the Ebu Hayyam Lugâtı, dated to the 14th century. ${ }^{25}$ From the archives in the Rum Seljuk and Ottoman periods, we learn that yorgans were made in several cities, especially Ankara, Bursa, Iğdır, Mersin and Maçka, after the Turks settled in Anatolia. ${ }^{26}$ From the Narh Defteri, we learn that the surface of yorgans was made of cotton including yazma (block printed textile), or silk, such as ibrişim silk. $^{27}$ The entire material was then filled with cotton or wool and used to make covers, wrapping and cloths. Generally, yorgans have two or three borders and a main surface decorated with floral designs and geometric motifs in the center. According to Evliya Çelebi, yorgans made of blocked-printed textiles were mainly prepared in Tokat. ${ }^{28}$ High-quality yorgans were prepared from chintz textiles, a type of Indian canfes textile. ${ }^{29}$

\footnotetext{
${ }^{20}$ NLI Aleph Catalog, Goitein, Shelomo Dov, Letters of medieval Jewish traders, Budapest, MTA: 311, Alt: 3, 6 . See: https://fjms.genizah.org/

${ }^{21}$ Miriam Frenkel and Nadia Zeldes, "The Sicilian Trade-Jewish Merchants in the Mediterranean in the 12th and 13th centuries," in Gli ebrei in Sicilia, dal Tardonatico al medioevo. Studi in Onore di Mons, Benedetto Rocco, ed. Nicolo Bucaria (Palermo: Flaccovio Editore, 1998), 243-256: 243.

${ }^{22}$ Jin silk quilt (1-3 warp faced compound tabby), L. 168cm, W. 94cm, China National Silk Museum, Hangzhou. See: Legacy of the Desert King, ed. Feng Zhao and Zhiyong Yu (Hangzhou, 2000), 72-73.

${ }^{23}$ Mustafa Duman, Istanbul'da Geleneksel Yorgancılık Sanatı (Istanbul, 2016), 15.

${ }^{24}$ Kâşgarlı Mahmûd, Divânü Lugâti’t Türk, trans. and ed. Seçkin Erdi (Istanbul, 2005), 699.

${ }^{25}$ Duman, Yorgancilık Sanatı, 15.

${ }^{26}$ Halil Inalcık, Türkiye Tekstil Tarihi üzerine Araştırmalar (Istanbul: Türkiye İş Bankası Kültür Yayınları, 2008), 269.

${ }^{27}$ Inalc1k, Türkiye Tekstil Tarihi üzerine Araştırmalar, 254.

${ }^{28}$ Inalcık, Türkiye Tekstil Tarihi üzerine Araştırmalar, 133.

${ }^{29}$ Inalcık, Türkiye Tekstil Tarihi üzerine Araştırmalar, 90, 93, 101, 103.
} 
Since the medieval period, Europeans imported cotton from Syria, India, Turkey, Cyprus, Egypt and Malta. In the 14th and 15th centuries, Venice imported 8000 bales of pure cotton annually from Syria. ${ }^{30}$ At the end of the 16th century, the amount of imported cotton from the Levant reached 20,000 bales (14,000 bales from Cyprus and 6,000 bales from Izmir) annually. ${ }^{31}$ Among products sold in Avignon in 1392, we find the word "cotone turchesho." 32 Since the Seljuk period, cotton was also cultivated in Anatolia and many cities became famous for their weaving industry, such as Konya, Kırşehir, Ladik and Denizli. At the end of the 15th century, the Italian Benedetto Dei purchased cotton from Bursa and sold it to the Florentines. ${ }^{33}$ Besides south and west Anatolian ports, ${ }^{34}$ cotton was sent to Spain, Ancona and Mallorca from the port of Foça, a small city on Aegean coast. Chios Island, located in the Aegean Sea, became a trading post where Anatolian cotton products were stored and exported to Europe by Genoese merchants. ${ }^{35}$ Not only cotton, but also cotton-silk blended fabrics were popular with the Ottomans, and these fabrics were used to make quilts. ${ }^{36}$ Both cotton itself and products made from it were exported to Europe.

The Caffa customs register of 1487-1490 lists imported and exported goods sent to Caffa from Anatolia. From these lists, we learn that quilts and materials for making quilts were brought to Caffa from Ankara, Istanbul and Kastamonu in Anatolia by Muslim merchants. We learn that nine quilts (yorgans with cotton) were brought from Ankara, each priced 100 akçe $^{37} ; 34$ materials for making quilts were brought from Istanbul and Kastamonu at 50 akçe per piece; quilt-making materials were brought from Aydın by the ship of Yusut Faki (Fakih). ${ }^{38}$ Haci Mehmed of Ankara brought ready-made quilts to $\mathrm{Caffa}^{39}$; 18 quilt-making materials were brought by Mehmed of Kefe $(\mathrm{Caffa})^{40}$; and Haci Kurban of Kastamonu. ${ }^{41}$ Together with unrefined cotton, Italian merchants purchased these quilted covers in Caffa and sold them in Europe from the early Ottoman period onward. Clothes were also made using the same quilted technique. Several caftans made with quilted textiles can be found at the Topkap1 Palace Museum and in private collections. ${ }^{42}$

\footnotetext{
${ }^{30}$ Inalc1k, Türkiye Tekstil Tarihi üzerine Araştırmalar, 78.

${ }^{31}$ Inalcık, Türkiye Tekstil Tarihi üzerine Araştırmalar, 78.

${ }^{32}$ Kate Fleet, Erken Osmanlı Döneminde Türk-Ceneviz Ticareti (Istanbul: İş Bankası, 2009), 99.

${ }^{33}$ Fleet, Türk-Ceneviz, Ticareti, 99.

${ }^{34}$ Nebi Bozkurt, "pamuk," in TDV İslam Ansiklopedisi 34 (Istanbul, 2007), 154-156.

${ }^{35}$ Inalcık, Türkiye Tekstil Tarihi üzerine Araştırmalar, 78.

${ }^{36}$ Inalcık, Türkiye Tekstil Tarihi üzerine Araştırmalar, 79.

${ }^{37}$ Halil Inalc1k, Sources and Studies on the Ottoman Black Sea, vol.1, The Customs Register of Caffa 1487-1490 (Harvard University, 1996), 121; Inalc1k 2008, 79-80.

${ }^{38}$ Inalcık, Sources and Studies, 57.

${ }^{39}$ Inalc1k, Sources and Studies, 58.

${ }^{40}$ Inalc1k, Sources and Studies, 65.

${ }^{41}$ Inalc1k, Sources and Studies, 68.

${ }^{42}$ See the caftan of Sultan II. Osman (reign: 1618-1622). Ottoman, 17th century, Silk satin (atlas), L. $123.5 \mathrm{~cm}$, Topkapı Palace Museum, inv.no. 13/305. Prof. Dr. Hülya Tezcan suggested that I research Şam hırkası made with a different quilting technique. But I was unable to find a reference to Şam hırkası in archives. I plan to pursue this subject in future studies.
} 


\section{Trapunto works in Europe}

It seems that these Turkish yorgans were in high demand in Europe. In medieval Europe, quilting techniques that used wool filling were used to make clothes and armors. ${ }^{43}$ One of the quilt techniques that I earlier referred to, the trapunto technique was used to achieve a threedimensional effect to emphasize the motifs. Raised-work with cords was frequently used in European silk embroidery in the 13th and 14th centuries. Good examples can be seen in the embroidery works of Opus Anglicanum in England. In England, the materials used to create these works were imported from Italy, Spain and Middle Eastern countries by Italian merchants beginning in the 11 th century. ${ }^{44}$

Examples of the earliest trapunto textiles that survived to the present day can be found at the Victoria and Albert Museum in London ${ }^{45}$ and the Bargello Museum in Florence. ${ }^{46}$ It is known that these quilted covers, coming from the same Florentine Guicciardini family, depict scenes from the legend of Tristan and Isolde. It is said that they were made in Sicily in ca. 1360-1400. ${ }^{47}$ In the medieval period, the textiles were used as a medium of communication for the narration of epic events. As Kathryn Berenson pointed out, the Bayeux tapestry is a good example of this. ${ }^{48}$ The "Tristan" quilt at the V\&A, sized $320 \mathrm{~cm} \times 287 \mathrm{~cm}$, was made with two layers of linen, stitched together with brown and white linen thread in backstitch. Using the trapunto technique, the motifs were filled with cotton wadding and cord quilting. As for the "Guicciardini" quilt at the Bargello Museum, it contains eight scenes and its size is $246 \mathrm{~cm} \times 205 \mathrm{~cm}$. Like the V\&A piece, it is padded with cotton, and depicts legendary scenes backstitched in cream and brown linen thread with captions. This covers depicts local characteristics of southern Italy, in particular of Sicily. ${ }^{49}$ For the purpose of this study, it is important to highlight that this piece is also made of three loom-width panels sewn together, just like the Benaki quilted cover.

The presence of trapunto covers in medieval Europe is confirmed by literary references, images on decorative objects, and documents from the $12^{\text {th }}$ century. ${ }^{50}$ According to Stefania Coccato's

\footnotetext{
${ }^{43}$ See: Surcoat (jupon) in the Canterbury Cathedral (inv.no. 01107) collection in England, before 1376. The surcoat is made with linen in plain weave, padded with wool and covered with silk velvet.

${ }^{44}$ English Medieval Embroidery, Opus Anglicanum, ed. Clare Browne, Glyn Davis and M.A. Michael etc. (Yale Univ Press. New Haven and London, 2016), exhibition catalog of the Victoria and Albert Museum, 44; Kathryn Berenson, "A brief history of white quilted embroidery" in La "coperta" Guicciardini Il restauro delle imprese di Tristano (Firenze, 2010), 49-54: 49.

${ }^{45}$ The Tristan quilt, $320 \mathrm{~cm}$ x 287cm, Sicily, 1360-1400. The Victoria and Alberto Museum, inv. no. 1391-1904. See: http://collections.vam.ac.uk/item/O98183/the-tristan-quilt-bed-cover-unknown/

${ }^{46}$ The Guicciardini quilt, 246 x $205 \mathrm{~cm}$, Sicily, after the second half of the 14th century. See: Conti and Stragapede, "Studio teorico-pratico della tecnica esecutiva," 68, 69.

${ }^{47}$ Kathryn Berenson suggests that these quilts were made by Neapolitan needle workers. see: Kathryn Berenson, "Italian Bedfellows: Tristan, Solomon \& Bestes" in The Social Fabric: Deep Local to Pan Global; Proceedings of the Textile Society of America 16th Biennial Symposium, presented at Vancouver, BC, Canada; September 19 - 23, 2018. https://digitalcommons.unl.edu/tsaconf/

${ }^{48}$ Berenson, "A brief history," 49.

${ }^{49}$ Conti and Stragapede, "Studio teorico-pratico della tecnica esecutiva," 70.

${ }^{50}$ Berenson, "A brief history," 49.
} 
doctoral dissertation entitled "Interni veneziani trecenteschi La cultura materiale attraverso gli inventari di beni mobili dei Procuratori di San Marco," blankets are frequently listed in the inventories included in many wills. ${ }^{51}$ Among the common terms used for blankets, the word traponta / trapontam / trapunta can be frequently found in 14th century inventories, although they do not specify details and differences. As for the decorations and techniques used in creating these blankets, Coccato writes of a blanket decorated with a lavorieri tartaresci, together with other decorations such as flowers, leaves, family crest, lions, French work, waves and bands of fabric in alternating colors. The old Venetian word a lavorieri tartaresci means panni tartarici / tartareschi, and this could refer to "oriental textiles" from Turkey, Iran or Central Asia. However, Jacoby states in his article that Italian artisans produced imitations of ornamental elements appearing on oriental silks. These artisans took those reproductions beyond mere imitation, creating highly imaginative new designs that integrated oriental elements. ${ }^{52}$ Actually, some tatar silk works were identified as imitations of oriental silks and tentatively ascribed to Venice, dated to the second half of the 13 th or the early 14 th century. ${ }^{53}$ From these contexts, we surmise that the type of blankets made with a lavorieri tartaresci must be predecessors or the same type of the Benaki quilted cover; and this type of quilted blanket was already produced in the 14 th century.

Likewise, cloths, ribbons, gowns and furnishing such as curtains of sarsenet are mentioned in the royal wardrobes, dated to the 14th century. Sarsenet or sarcenet is a type of fine, thin silk fabric in plain or twill weaves and was used for lining. ${ }^{54}$ The name is derived from the word Saracen, which was used for Arab, Syrian or Turkish Muslims. Another common type of fabric, white fabric made of cotton, linen or both, was called bucherame, bougran, bouqueran, buharin and bukram - all referring to the Eastern textile bukram. Marco Polo (1254-1324) mentions that the "bougran of Arzinga" (Erzincan in present-day Turkey) was the best in the world. ${ }^{55} \mathrm{He}$ also mentions buharin cotton fabrics in Mardin. ${ }^{56}$ These historical references show us that fabrics such as bukram and sarsenet were mainly imported from Asia Minor.

\footnotetext{
${ }^{51}$ See: Coccato, Stefania, "Interni veneziani trecenteschi, La cultura materiale attraverso gli inventari di beni mobili dei Procuratori di San Marco," (PhD. diss., Universita Ca'Foscari, IUAV Universita di Verona, 2016); also see: David Jacoby, "Silk Economics and Cross-Cultural Artistic Interaction: Byzantium, the Muslim World and the Christian West," Dumbarton Oaks Papers, Vol. 58 (2004): 208, http://links.jstor.org/sici?sici=00707546\%282004\%2958\%3C197\%3ASEACAI\%3E2.0.CO\%3B2-J; David Jacoby, "Marco Polo, His Close Relatives, and His Travel Account: Some New Insights," Mediterranean Historical Review Vol.21, No.2 (December 2006): 205.

52 Jacoby, "Silk Economics and Cross-Cultural Artistic Interaction," 236.

${ }^{53}$ Jacoby, "Silk Economics and Cross-Cultural Artistic Interaction ," 235, footnote 218.

${ }^{54}$ Edgcumbe Staley mentions that Sarcenet (Drappi della Ermisini), a light kind of silk tissue, which admitted of the admixture of inferior and watered down materials, was much made in the Guild of Silks of Florence. However, this was discouraged and under certain conditions forbidden, as detracting from the reputation of the Florentine silk manufacturers. See: Edgcumbe Staley, The Guild of Florence (London: Methuen \& Co., 1906), 223.

${ }^{55}$ Abdulhalik Bakır, "Ortaçağ Islam Dünyasında Dokuma Sanayi,” Belleten (Aralık 2000): 767.

${ }^{56}$ Bakır, "Ortaçağ Islam Dünyasında Dokuma Sanayi,” 767.
} 
From these examples, we understand that European artisans and craftsmen imitated Eastern textiles to meet the demand in Europe. Quilted cover yorgan, an Asia Minor product, was one of them. Most probably, quilted covers imported to Europe by Italian merchants along with other textiles were imitated by Italian artisans, who went on to produce a new type of quilted textile using the trapunto technique. The trapunto technique was used not only for bed covers or coverlets, but also to create wall hangings that were used to decorate the interior of castles. Just like other textiles and carpets, these textiles too were displayed outdoors on special occasions, as shown in a 13 th century French poem. ${ }^{57}$

Trapunto embroidery works were exported to various places in Europe to meet the demands for these textiles by members of the royalty, aristocrats, nobles and other upper classes in Europe, and they were copied elsewhere in Europe, especially in France, Portugal, and England. Quilts made in Provence provide a good example of this custom. Similar types of corded quilting can be found in Marseilles after the 17th and 18th centuries. Marseilles work, Provincial corded quilting or Piqûre de Marseilles is made from white cotton fabrics embroidered with cotton yarns and filled with cotton cords, using a different method than the trapunto technique. The geometrical motifs on the Piqûre de Marseilles, in a private collection, dated to the second half of the 18th century, are eye-catching. (Fig. 11) This is a rare example of a geometrical composition in Marseilles-style corded quilting, which generally features floral compositions and designs. While this subject is outside the scope of our study, we surmise that this cover was made under the influence of trapunto fiorentino.

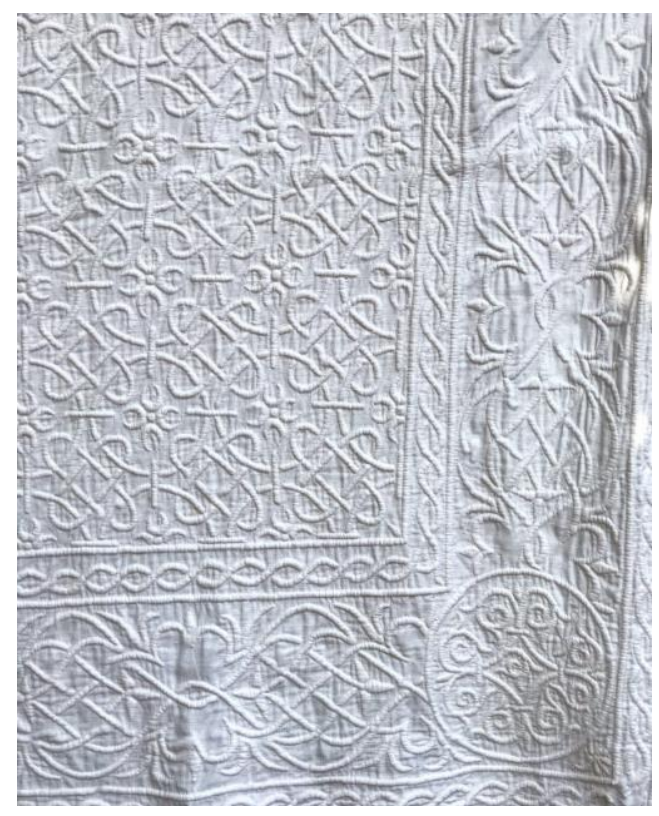

Fig. 11, Piqûre de Marseilles, Provence, second half of the 18th century

$256 \times 281 \mathrm{~cm}$, Private collection. Photo: CVilla Rosemarine, France

\footnotetext{
${ }^{57}$ Berenson, “A brief history," 49.
} 


\section{The emblem of the double-headed eagle}

The emblem of the double-headed eagle provides a strong argument in support of my hypothesis that the Benaki cover is made in Italy. The double-headed eagle on the Benaki quilted cover spreads its wings and splays its three-clawed legs on the left and right. (see Fig. 7) it differs from the Byzantine or Spanish eagle, which has different features, such as a crown above its head, a coat of arm on its chest, epaulette with animal or ornamental decoration on its shoulders, and animals such as deer and lion on the left and right under its legs. None of these features exist in the quilted cover at the Benaki collection.

According to Pascal Androudis, a Buyid Iran silk fragment with a double-headed eagle was used to wrap the body of a deceased royal person. ${ }^{58} \mathrm{He}$ also argues textiles with double-headed eagles attributed to Andalusí workshops were found in tombs and were used to cover the remains of Christian saints. ${ }^{59}$ As mentioned above, a cover in the Han dynasty was used for the same purpose. Androudis indicates that the practice of wrapping the bodily remains of Christian saints in precious textiles, often imported from the eastern Mediterranean, the Near East, Spain or Sicily, is well attested from at least the 11 th century onward ${ }^{60}$ Similarly, Ballian also notes that quilted covers were used in a family tradition of covering the death bed of their owners. ${ }^{61}$ Actually, the geometric motifs on the trapunto cover are reminiscent of Islamic textiles decorated with calligraphy. One may argue that this type of quilt was influenced by Islamic textiles, which were used as coffin covers in Islamic countries. Geometric motifs on the surface of the quilted cover may have been modeled on Arabic calligraphy seen in Islamic fabrics. These motifs were expressed as pseudo-calligraphic designs and made with the trapunto technique. The reason for the predominance of geometric patterns in the design might be to increase the value of the quilted covers by imitating the precious textiles from the East. Likewise, the addition of the double-headed eagle motif in the center of the quilted cover may also have been done to increase the value of the cover.

After Charles I of Anjou occupied Sicily in 1266, the Sicilian weaving industry and weavers moved to Italy, which led to the flourishing of the Lucchese silk industry. As we know, Sicily inherited a textile tradition from Islamic North Africa and Spain and blended it with new features and techniques, which were brought by Greeks who were taken to Sicily by King Rogers II in 1147 after he captured Thebes and Corinth. This Byzantine heritage, such as roundels containing paired animals, can be seen on Lucchese silk weavings. Byzantine influence was not limited to designs and compositions, but also adopted weaving techniques of a variety of Byzantine style silks, such as samite and half-silks incorporating linen. ${ }^{62}$ In this context, it is hardly surprising to

\footnotetext{
${ }^{58}$ Androudis, "Double-headed Eagles," 322.

${ }^{59}$ Androudis, "Double-headed Eagles," 325.

${ }^{60}$ Androudis, "Double-headed Eagles," 325; Ballian, "From Genoa to Constantinople," 89.

${ }^{61}$ Ballian, "From Genoa to Constantinople," 89: she says that a similar quilt is depicted on the death bed of the Virgin in a painting by Bartolome Bermejo in 1460-62.

${ }^{62}$ Lisa Monnas, Merchants, Prices and Painters: silk fabrics in Italian and northern paintings, 1300-1550 (London, 2008), 5, 6; Jacoby mentions that the resettlement of Byzantine silk workers in Palermo injected Byzantine elements
} 
find the double-headed eagle on the trapunto quilted covers made in Italy. These Italian textiles were exported not only to Europe but also to the Mediterranean region by Levant merchants. Trapunto covers were likely among them; and members of the nobility would have bought and kept them as family treasures.

This type of trapunto quilted cover was also imitated in Southern Europe and produced using similar techniques, such as butis. A Marseille white cotton quilted cover in a private collection, dated to the 17th century, is a good example. Made in Provence, the quilted cover is sized $82 \mathrm{~cm}$ high $x 78 \mathrm{~cm}$ wide. Inside the square on the surface, a double-headed crowned eagle is embroidered with the butis technique, called vermicelles. The eagle is surrounded by four lions and two birds, above and below. (Fig. 12 and 13) While some motifs and compositions in quilted covers made in Southern Europe in the 17th century seem to have changed, the eight petal flower motifs on four corners reminded. ${ }^{63}$ Other two extant quilts also bear double-eagles in the corners. ${ }^{64}$ These quilted covers show how composition styles and designs coalesced as conventional iconography over the centuries using a particular pattern and similar techniques.
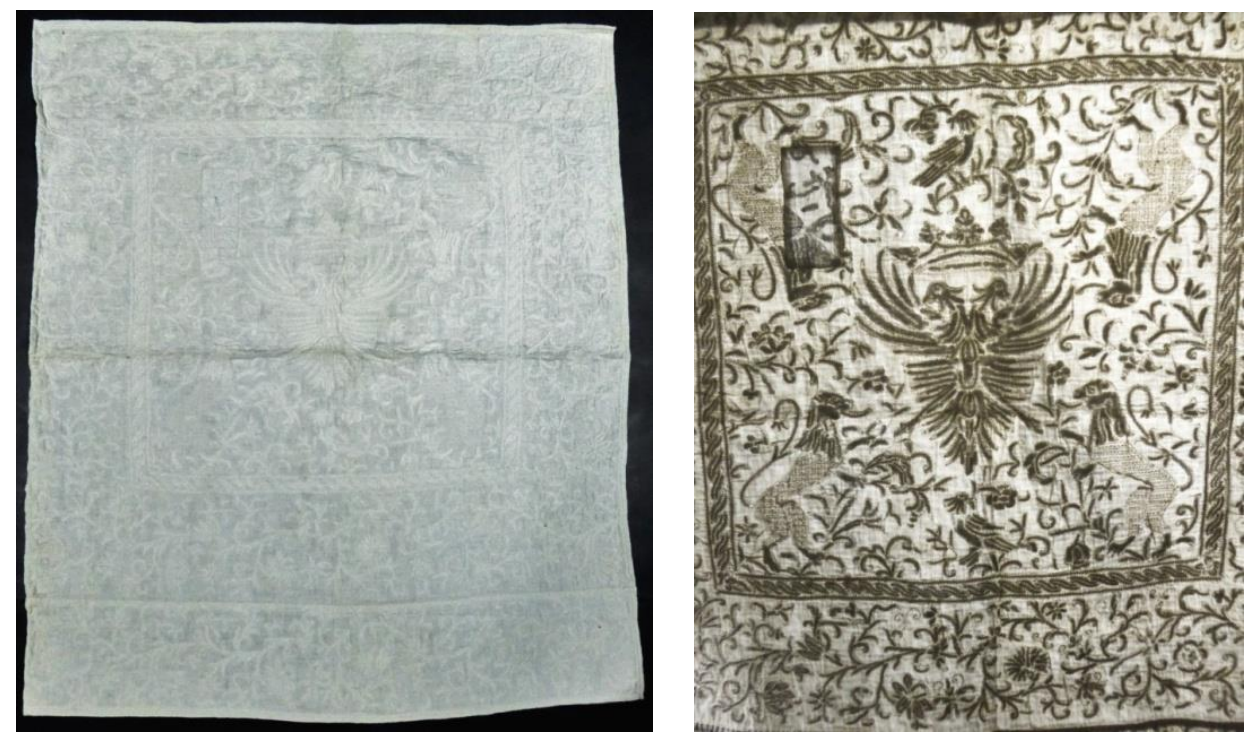

Fig. 12 and 13, quilted Marseille embroidery with double-headed crowned eagle and lions. $82 \mathrm{~cm}$ high $\times 78 \mathrm{~cm}$ wide, Provence, 17th century or first half of the 18th century,

Private collection. Photo: CVilla Rosemarine, France

into the textiles manufactured in the existing royal atelier. For further information, see: David Jacoby, "Silk Economics," 227.

${ }^{63}$ See the silk quilt with cotton filling made in Southern Europe, $17^{\text {th }}$ century, in Interwoven Globes, The Worldwide Textile Trade, 1500-1800, ed. Amelia Peck (New York: The Metropolitan Museum of Art, New York, 2013), 138, Cat. 1 and 139, fig. 123.

${ }^{64}$ Interwoven Globes, 139. 


\section{Conclusion}

Since medieval times, many precious textiles were imported into Europe from the Middle East, and quilted textiles were among them. As demand increased, Italian artisans began imitating these and created new types of quilted textiles using the trapunto technique. The predominance of geometric patterns in the design can be explained by the intent to increase the value of the quilted cover by making them appear more similar to precious textiles from the East.

Traditionally, quilted covers with the double-headed eagle motif, including the Benaki piece, might have been used to cover the body of a deceased person on his or her deathbed. While COVID-19 conditions delayed color analysis of the textiles, it can be said that the trapunto quilted cover in the Benaki Museum was made in Italy, most probably Florence or Venice in the 16th century, based on its pattern that is more sophisticated and complicated than the Italian trapunto fragment, and more classic than other existing trapunto quilted covers, dated to the 17 th century.

\section{Acknowledgements}

I would like to express my gratitude to Ms. Mina Moraitou (The Benaki Museum), Dr. Alberto Boralevi, Dr. Marco Mozzo (The Giardino della Villa di Castello, Museo e Galleria Mozzi Bardini), and Mr. Serge Liagre (Villa Rosemarie) for giving me permission to use images and information of the art work in their collection. I am grateful to Dr. Alberto Boralevi, Mr. Beşir Bostan, Mr. Engin Gündoğan, Prof. Dr. Takao Ito (University of Kobe), Ms. Nobuko Kajitani, Ms. Güler Köknar, Mr. Hugh Jeff Turner, and the Textile Society of America for their kind help and support in the preparation of this paper.

\section{Selected bibliography}

Androudis, Pascal. "Double-headed Eagles on Early (11th-12th C.) Medieval Textiles Aspects of Their Iconography and Symbolism." In Niš i Vizantija: cetrnaesti medunarodni naucni skup, Niš, 3.-5. Jun 2015: zbornik radova XIV: Dani Sv. cara Konstantina i carice Jelene (Niš and Byzantium: fourteenth International Symposium, Niš, 3-5 June 2015: the collection of scientific works XIV: The Days of St. Emperor Constantine and Helena). Edited by Rakocija, Miša B., 315-342. Nis, 2016.

Bakır, Abdulhalik. "Ortaçağ Islam Dünyasında Dokuma Sanayi.” Belleten, Sa. 241(Aralık 2000): 749-826.

Ballian, Anna. "From Genoa to Constantinople: The Silk Industry of Chios." In The Mercantile Effect, Art and Exchange in the Islamicate World during the 17th and 18t centuries. Edited by Sussan Babaie and Melanie Gibson, 87-101. London: Gingko, 2018.

Berenson, Kathryn. "Italian Bedfellows: Tristan, Solomon \& Bestes." In The Social Fabric: Deep Local to Pan Global; Proceedings of the Textile Society of America 16th Biennial Symposium. Presented at Vancouver, BC, Canada; September 19-23, 2018. https://digitalcommons.unl.edu/tsaconf/ 
Berenson, Kathryn. "A brief history of white quilted embroidery." In La "coperta" Guicciardini Il restauro delle imprese di Tristano, 49-54. Firenze, 2010.

Book of Gifts and Rarities (Kitab al-Hadaya wa al-Tuhaf). Translated by Ghada al-Hijiawi alQaddumi. The President and Fellows of Harvard College, 1996.

Cavallo, Adolph S. Textiles: Isabella Stewart Gardner Museum. Boston, 1986.

Coccato, Stefania. "Interni veneziani trecenteschi, La cultura materiale attraverso gli inventari di beni mobili dei Procuratori di San Marco." PhD diss., Universita Ca'Foscari, IUAV Universita di Verona, 2016.

Conti, Susanna and Maria Stragapede. "Studio teorico-pratico della tecnica esecutiva." In La "coperta" Guicciardini Il restauro delle imprese di Tristano, 67-80. Firenze, 2010.

Frenkel, Miriam and Nadia Zeldes. "The Sicilian Trade-Jewish Merchants in the Mediterranean in the 12th and 13th centuries." In Gli ebrei in Sicilia, dal Tardonatico al medioevo. Studi in Onore di Mons, Benedetto Rocco. Edited by Nicolo Bucaria, 243-256. Palermo: Flaccovio Editore, 1998.

Inalc1k, Halil. The Customs Register of Caffa 1487-1490. Harvard University, 1996. Inalcık, Halil. Türkiye Tekstil Tarihi üzerine Araştırmalar. Istanbul: Türkiye İş Bankası Kültür Yayınları, 2008.

Jacoby, David. "Silk Economics and Cross-Cultural Artistic Interaction: Byzantium, the Muslim World and the Christian West." Dumbarton Oaks Papers, Vol. 58 (2004):197-240.

http://links.jstor.org/sici?sici=00707546\%282004\%2958\%3C197\%3ASEACAI\%3E2.0.CO\%3B 2-J

Lane, Edward William. An Arabic-English Lexicon. Book I, Part 8. Edited by Stanley LanePoole. London: Williams and Norgate, 1885.

Monnas, Lisa. Merchants, Prices and Painters: silk fabrics in Italian and northern paintings, 1300-1550. London, 2008.

Serjeant, R. B. Islamic Textiles: Material for a History up to the Mongol Conquest. Beirut, 1972. Staley, Edgcumbe. The Guild of Florence. London: Methuen \& Co., 1906. 